\title{
DETERMINATION OF ACUTE TOXICITY OF THE 'BONDARMIN' DISINFECTANT WHEN ADMINISTERED INTRAPERITONEALLY TO LABORATORY ANIMALS
}

\author{
Bondarchuk A. O. ${ }^{1}$, Paliy A. P. ${ }^{2}$, Palii A. P. ${ }^{3}$, Aksonov A. P. ${ }^{1}$ \\ ${ }^{1}$ Kharkiv State Zooveterinary Academy, Kharkiv, Ukraine, e-mail: ancheystar777@ukr.net \\ ${ }^{2}$ National Scientific Center 'Institute of Experimental and Clinical \\ Veterinary Medicine', Kharkiv, Ukraine, e-mail: paliy.dok@gmail.com \\ ${ }^{3}$ Kharkiv Petro Vasylenko National Technical University \\ of Agriculture, Ukraine, Kharkiv, e-mail: paliy.andriy@ukr.net
}

\begin{abstract}
Summary. The article presents the results of the study of the acute toxic effect of the innovative disinfectant 'Bondarmin' (active substance - potassium peroxomonosulfate) on laboratory animals (mice, rats) are presented. Many scientific works of scientists in recent years have been devoted to the study of the toxicity of various disinfectants both in our country and abroad. However, today there are many topical issues regarding the toxicity and safety of some antimicrobials. Our work aimed to study the toxic effect on the laboratory animals and to establish the acute toxicity $\left(\mathrm{LD}_{50}\right)$ of the developed disinfectant 'Bondarmin' when administered intraperitoneally. Experiments were carried out in the Laboratory of Pharmacology and Toxicology of the National University of Pharmacy (Kharkiv) and in the Educational and Scientific Laboratory of Genetic and Molecular Research Methods named after P. I. Verbitskiy in the Kharkiv State Zooveterinary Academy. Acute toxicity assessment $\left(\mathrm{LD}_{50}\right)$ was carried out with intraperitoneal administration of the designed disinfectant to laboratory animals (mice, rats). The toxic effect of the newly developed disinfectant 'Bondarmin' for the intraperitoneal method of administration to laboratory animals (mice, rats) has been determined. For the intraperitoneal administration of the 'Bondarmin' disinfectant, the $\mathrm{LD}_{50}$ by Prozorovskiy method is $316.85 \pm 19.26 \mathrm{mg} / \mathrm{kg}$ for mice, and $279.33 \pm 19.80 \mathrm{mg} / \mathrm{kg}$ for rats. The disinfectant belongs to the IV toxicity class (low toxic substances). The results of toxicological studies allow us to recommend the use of 'Bondarmin' for disinfecting livestock facilities
\end{abstract}

Keywords: lethal dose, potassium peroxomonosulfate, mice, rats, disinfection

Introduction. The sanitary-epidemiological situation in animal husbandry today is characterized by a tendency to the emergence and spread of infectious diseases with respiratory and fecal-oral routes of transmission. This is facilitated by the irrational use of antibiotics, violation of the sanitary regime, untimely implementation of measures for non-specific prevention of infectious diseases, which include disinfection of livestock facilities. Disinfection is an effective measure for the prevention and elimination of all known diseases in both human (Al-Sayah, 2020; Takagi and Yagishita, 2020; Cimolai, 2020) and veterinary (Stegniy et al., 2019; Shkromada et al., 2019; Paliy et al., 2020c) medicine.

Extensive use of antiseptics and disinfectants has led to some assumptions about the development of microbial resistance, including cross-resistance to antibiotics (McDonnell and Russell, 1999).

At present, in the field of domestic disinfection there is significant information on the resistance of microorganisms to different groups of disinfectants. The range of effective drugs has been expanded, disinfection techniques have been developed and implemented (Rutala and Weber, 2016; Saccucci et al., 2018; Paliy and Paliy, 2019).

The range of disinfectants is represented by a wide variety of chemical compounds of various origins and is quite extensive. However, the existing disinfectants have a significant difference from each other, have different antimicrobial action, toxicity, corrosion (Zavgorodniy et al., 2013; Lin et al., 2020). Aldehyde compounds (Paliy et al., 2016, 2018, 2020a; Gedge, Hollingsworth and Suchmann, 2019), organochlorine agents (Mustapha et al., 2018; Paliy et al., 2020b) have been shown to have a broad spectrum of antimicrobial activity. Along with that, in experimental studies, alcohol disinfection was not effective for 11 from $30(36.7 \%)$ and for 12 from 62 (19.4\%) subjects, respectively (Ribeiro et al., 2015).

The study of the toxicity of any drug for further testing and production is a necessary step, which is provided by the current instructional requirements (Kotsiumbas et al., 2006; Nechyporenko et al., 2019; Kovalenko et al., 2020; Orobchenko et al., 2020). Previously, data were published on the results of study of acute toxicity of the disinfectant 'Bondarmin' when administered intragastrically to laboratory mice (Bondarchuk, Paliy and Blazheyevskiy, 2019).

The aim of the study was to investigate the toxic effects of the disinfectant 'Bondarmin' on laboratory animals (mice, rats) when administered intraperitoneally.

Material and methods. We determined the toxicological properties of the 'Bondarmin' disinfectant, which is a domestic import-substituting development. Laboratory studies were performed using the rapid method to study moderately lethal doses of chemical 
compounds (Pastushenko et al., 1985). The least squares method was used to analyze mortality curves (Prozorovskiy, 1962).

For experimental studies outbred white mice and Wistar rats were used. Mice were grown in the vivarium of the Kharkiv State Zooveterinary Academy and prior to the experiment they had undergone acclimatization under the conditions of the testing room for 7-10 days. The animal keeping conditions complied with the current rules for vivarium devices, equipment and maintenance. In accordance with the code of practice, animals received standard nutrition (CEC, 2010).

Animals were treated in accordance with the requirements of the Commission on Bioethics and the General Ethical Principles of Experiments on Animals, consistent with the provisions of the 'Directive 2010/63/EU of the European Parliament and of the Council of 22 September 2010 on the protection of animals used for scientific purposes' (CEC, 2010).

The acute toxicity of 'Bondarmin' was studied on laboratory animals (mice, rats) trough intraperitoneal administration to reproduce the acute poisoning clinic and to determine the $\mathrm{LD}_{50}$.

Results and discussion. Acute toxicity studies were performed in two stages. To determine the toxicity parameters at the preliminary stage, the express method of Pastushenko et al. (1985), and finally, the least-squares method for probit analysis of mortality curves according to Prozorovskiy (1962) ware used. The study of acute toxicity was performed with a single intraperitoneal route of administration.

For the preliminary stage of the study, all animals, mice and rats, respectively, were divided into seven groups of four in each. A dose interval ranging from 158 to $398 \mathrm{mg} / \mathrm{kg}$ was selected. Disinfectant was administered to animals in the form of an aqueous solution intraperitoneally using a syringe with a needle. The animals were observed for 14 days (Table 1).

Table 1- Mortality of laboratory animals after intraperitoneal administration of the 'Bondarmin' disinfectant $(\mathrm{n}=4)$

\begin{tabular}{|l|c|c|c|c|c|c|c|}
\hline \multirow{2}{*}{ Caused effect } & \multicolumn{7}{|c|}{ Dose, $\mathbf{~ m g} / \mathbf{k g}$} \\
\cline { 2 - 7 } & $\mathbf{1 5 8}$ & $\mathbf{2 0 0}$ & $\mathbf{2 5 0}$ & $\mathbf{2 8 2}$ & $\mathbf{3 1 6}$ & $\mathbf{3 5 5}$ & $\mathbf{3 9 8}$ \\
\hline \multicolumn{7}{|c|}{ Mice, males } \\
\hline $\begin{array}{l}\text { Dead animals/ } \\
\text { total number }\end{array}$ & - & $0 / 4$ & $0 / 4$ & $2 / 4$ & $2 / 4$ & $4 / 4$ & $4 / 4$ \\
\hline \multicolumn{1}{|c|}{$\begin{array}{l}\text { Read animals/ } / 4 \\
\text { total number }\end{array}$} & $0 / 4$ & $0 / 4$ & $2 / 4$ & $2 / 4$ & $4 / 4$ & $4 / 4$ & $4 / 4$ \\
\hline
\end{tabular}

According to the results of studies, the death of mice was observed with the introduction of disinfectant at a dose of $282 \mathrm{mg} / \mathrm{kg}$ and higher, and rats $-250 \mathrm{mg} / \mathrm{kg}$ and higher. The required dose range was selected to calculate the $\mathrm{LD}_{50}$. The sequence of animal deaths 2-2-4 was used for this purpose. In doses for mice it is 282,316 , and $355 \mathrm{mg} / \mathrm{kg}$, for rats $-250,282$, and $316 \mathrm{mg} / \mathrm{kg}$. Using the table of the express method by Pastushenko et al. (1985) $\mathrm{LD}_{50}$ was determined. According to this method, the $\mathrm{LD}_{50}$ of the 'Bondarmin' disinfectant for mice is 330 $(272-387) \mathrm{mg} / \mathrm{kg}$, and for rats - $294(242-346) \mathrm{mg} / \mathrm{kg}$.

In order to confirm the above results and to study other toxicity parameters, we studied the acute toxicity of the disinfectant with intraperitoneal administration using the least-squares method for probit analysis of mortality curves by Prozorovsky (1962). Experimental groups were formed to determine the mean lethal dose. The animals were observed for 14 days after the introduction of disinfectant, recording the manifestations of disorders of the physiological state of the animals and mortality (Table 2).

Table 2- Mortality of adult male mice after intraperitoneal administration of the 'Bondarmin' disinfectant $(n=6)$

\begin{tabular}{|c|c|c|}
\hline $\begin{array}{c}\text { Animal } \\
\text { species, sex }\end{array}$ & $\begin{array}{c}\text { Dose, } \\
\mathbf{m g} / \mathbf{k g}\end{array}$ & $\begin{array}{c}\text { Caused effect, } \\
\text { dead animals/total number }\end{array}$ \\
\hline \multirow{4}{*}{ Mice, males } & 200 & $0 / 6$ \\
\cline { 2 - 3 } & 250 & $1 / 6$ \\
\cline { 2 - 3 } & 300 & $3 / 6$ \\
\cline { 2 - 3 } & 350 & $4 / 6$ \\
\cline { 2 - 3 } Rats, males & 400 & $6 / 6$ \\
\hline & 200 & $0 / 6$ \\
\cline { 2 - 3 } & 250 & $2 / 6$ \\
\cline { 2 - 3 } & 300 & $3 / 6$ \\
\cline { 2 - 3 } & 350 & $5 / 6$ \\
\cline { 2 - 3 } & 400 & $6 / 6$ \\
\hline
\end{tabular}

The results presented in Table 2 were the basis for calculating the parameters of the toxic action of the 'Bondarmin' disinfectant for mice using the method by Prozorovsky (1962) (Table 3).

The calculated parameters of LD for the 'Bondarmin' disinfectant when administered intraperitoneally to mice are: $\mathrm{A}_{0}=2.49 ; \mathrm{A}_{1}=0.79 ; \quad \mathrm{LD}_{16}=238.42 \mathrm{mg} / \mathrm{kg} ; \mathrm{LD}_{50}=$ $316.85 \mathrm{mg} / \mathrm{kg} ; \quad \mathrm{LD}_{84}=387.59 \mathrm{mg} / \mathrm{kg} ; \quad \mathrm{m}=19.26 \mathrm{mg} / \mathrm{kg}$ (the value of the average error obtained by calculating the $\mathrm{LD}_{50}$ of the experimental groups in accordance with this method). Therefore, $\mathrm{LD}_{50}=316.85 \pm 19.26 \mathrm{mg} / \mathrm{kg}$ or 316.85 (276.99-356.71) mg/kg.

In addition, the results presented in Table 2 were the basis for calculating the parameters of the toxic action of the 'Bondarmin' disinfectant for rats using the method by Prozorovsky (1962) (Table 4).

The calculated parameters of LD for the 'Bondarmin' disinfectant when administered intraperitoneally to rats are: $\mathrm{A}_{0}=2.70 ; \mathrm{A}_{1}=0.82 ; \mathrm{LD}_{16}=197.5 \mathrm{mg} / \mathrm{kg} ; \mathrm{LD}_{50}=$ $279.33 \mathrm{mg} / \mathrm{kg} ; \mathrm{LD}_{84}=350.6 \mathrm{mg} / \mathrm{kg} ; \mathrm{m}=19.8 \mathrm{mg} / \mathrm{kg}$ (the value of the average error obtained by calculating the $\mathrm{LD}_{50}$ 
of the experimental groups in accordance with this method). Therefore, $\mathrm{LD}_{50}=279.33 \pm 19.80 \mathrm{mg} / \mathrm{kg}$ or $279.3(238.00-320.27) \mathrm{mg} / \mathrm{kg}$.

When administered toxic doses in laboratory animals (mice, rats) the following signs of intoxication were observed: decrease in motor activity, lack of appetite, impaired coordination of movements, stupor developed, and then there was a death. Deterioration of the animals was recorded on the first or third day after administration of the disinfectant. The severity of these signs increased with increasing dose. At autopsy of dead animals we observed pathological changes in the abdominal cavity.

Thus, the parameters of acute toxicity of the 'Bondarmin' disinfectant on laboratory animals (mice, rats) have been determined. The research results are shown in Table 5.

Table 3 - Calculation data for the determination of the $\mathrm{LD}_{50}$ of the 'Bondarmin' disinfectant in mice after intraperitoneal administration by Prozorovskiy method

\begin{tabular}{|c|c|c|c|c|c|c|c|c|}
\hline Dose, mg/kg & Mortality, \% & Dose place $(\mathrm{X})$ & Probit (Y) & Weighting coefficient (B) & $\mathbf{x B}$ & $\overline{\mathbf{X}^{2} \mathbf{B}}$ & yB & xyB \\
\hline 200 & 0 & 1 & 3.27 & 1.6 & 1.60 & 1.60 & 5.23 & $\overline{5.23}$ \\
\hline 250 & 16.67 & 2 & 4.05 & 3.7 & 7.40 & 14.80 & 14.99 & 29.97 \\
\hline 300 & 50.00 & 3 & 5.00 & 5.0 & 15.00 & 45.00 & 25.00 & 75.00 \\
\hline 350 & 66.67 & 4 & 5.44 & 4.6 & 18.40 & 73.60 & 25.02 & 100.10 \\
\hline 400 & 100 & 5 & 6.73 & 1.6 & 8.00 & 40.00 & 10.77 & 53.84 \\
\hline \multicolumn{4}{|c|}{$\sum$} & 16.5 & 50.40 & 175.00 & 81.01 & 264.14 \\
\hline
\end{tabular}

Table 4 - Calculation data for the determination of the $\mathrm{LD}_{50}$ of the 'Bondarmin' disinfectant in rats after intraperitoneal administration by Prozorovskiy method

\begin{tabular}{|c|c|c|c|c|c|c|c|c|}
\hline Dose, $\mathrm{mg} / \mathrm{kg}$ & Mortality, \% & Dose place (X) & Probit $(\mathrm{Y})$ & Weighting coefficient (B) & $\mathbf{x B}$ & $\mathbf{X}^{2} \mathbf{B}$ & yB & xyB \\
\hline 200 & 0 & 1 & \begin{tabular}{|l|}
3.27 \\
\end{tabular} & 1.6 & 1.60 & 1.60 & 5.23 & 5.23 \\
\hline 250 & 33 & 2 & 4.56 & 4.5 & 9.00 & 18.00 & 20.52 & 41.04 \\
\hline 300 & 50 & 3 & 5.00 & 5.0 & 15.00 & 45.00 & 25.00 & 75.00 \\
\hline 350 & 87 & 4 & 6.13 & 3.2 & 18.40 & 73.60 & 24.89 & 99.54 \\
\hline 400 & 100 & 5 & 6.73 & 1.6 & 8.00 & 40.00 & 10.77 & 53.84 \\
\hline \multicolumn{4}{|c|}{$\sum$} & 17.3 & 52.00 & 178.20 & 86.41 & 274.66 \\
\hline
\end{tabular}

Table 5 - The degree of toxicity of the 'Bondarmin' disinfectant for different routes of administration to laboratory animals

\begin{tabular}{|c|c|c|c|c|c|}
\hline \multirow{2}{*}{ Route of administration } & \multirow{2}{*}{\multicolumn{2}{|c|}{$\begin{array}{l}\text { Animal species, } \\
\text { sex }\end{array}$}} & \multicolumn{2}{|c|}{$\mathrm{LD}_{50}, \mathrm{mg} / \mathrm{kg}$} & \multirow{2}{*}{$\begin{array}{l}\text { Toxicity } \\
\text { class }\end{array}$} \\
\hline & & & by Pastushenko et al. (1985) & by Prozorovsky (1962) & \\
\hline \multirow{2}{*}{$\begin{array}{l}\text { Intragastric (Bondarchuk, } \\
\text { Paliy and Blazheyevskiy, 2019) }\end{array}$} & mice & males & $2,580(1,930-3,220)$ & $2,702(2,379-3,026)$ & \multirow{4}{*}{$\begin{array}{c}\text { IV } \\
\text { (low toxic } \\
\text { substances) }\end{array}$} \\
\hline & rats & males & $2,940(2,420-3,460)$ & $3,014(2,483-3,544)$ & \\
\hline \multirow{2}{*}{ Intraperitoneal } & mice & males & $330(272-387)$ & $317(277-357)$ & \\
\hline & rats & males & $330(272-387)$ & $279(238-320)$ & \\
\hline
\end{tabular}

The 'Bondarmin' disinfectant for intragastric and intraperitoneal routes of administration to laboratory animals (mice, rats) belongs to the IV toxicity class (low toxic substances).

Conclusions. The toxic effect of the newly developed disinfectant 'Bondarmin' for the intraperitoneal method of administration to laboratory animals (mice, rats) has been determined. For the intraperitoneal administration of the 'Bondarmin' disinfectant, the median lethal dose by Prozorovskiy method is $316.85 \pm 19.26 \mathrm{mg} / \mathrm{kg}$ for mice, and $279.33 \pm 19.80 \mathrm{mg} / \mathrm{kg}$ for rats. The disinfectant belongs to the IV toxicity class (low toxic substances). The results of toxicological studies allow us to recommend the use of 'Bondarmin' for disinfecting livestock facilities.

\section{References}

Al-Sayah, M. H. (2020) 'Chemical disinfectants of disinfectant', Journal for Veterinary Medicine, Biotechnology and COVID-19: An overview', Journal of Water and Health, 18(5), pp. 843-848. doi: 10.2166/wh.2020.108.

Bondarchuk, A. O., Paliy, A. P. and Blazheyevskiy, M. Ye. (2019) 'Determination of acute toxicity of the "Bondarmin" Biosafety, 5(2), pp. 26-30. doi: 10.36016/JVMBBS-2019-5-2-5.

CEC (The Council of the European Communities) (2010) 'Directive 2010/63/EU of the European Parliament and of the Council of 22 September 2010 on the protection of animals used 
for scientific purposes', The Official Journal of the European Communities, L 276, pp. 33-79. Available at: http://data.europa. eu/eli/dir/2010/63/oj.

Cimolai, N. (2020) 'Environmental and decontamination issues for human coronaviruses and their potential surrogates', Journal of Medical Virology, 92(11), pp. 2498-2510. doi: 10.1002/ jmv.26170.

Gedge, L. M., Hollingsworth, A. L. and Suchmann, D. B. (2019) 'New disinfectants for inactivation and disinfection of Pseudomonas aeruginosa: Comparison with market leaders', Journal of Bacteriology \& Mycology: Open Access, 7(3), pp. 55-60. doi: 10.15406/jbmoa.2019.07.00243.

Kotsiumbas, I. Ya., Malyk, O. H., Patereha, I. P., Tishyn, O. L. and Kosenko, Yu. M. (2006) Preclinical studies of veterinary drugs [Doklinichni doslidzhennia veterynarnykh likarskykh zasobiv]. Lviv: Triada plus. ISBN 9667596648. [in Ukrainian].

Kovalenko, V. L., $\quad$ Ponomarenko, G. V., Kukhtyn, M. D., Paliy, A. P., Bodnar, O. O., Rebenko, H. I., Kozytska, T. G., Makarevich, T. V., Ponomarenko, O. V. and Palii, A. P. (2020) 'Evaluation of acute toxicity of the "Orgasept" disinfectant', Ukrainian Journal of Ecology, 10(4), pp. 273-278. doi: 10.15421/ 2020_1982.

Lin, Q., Lim, J. Y. C., Xue, K., Yew, P. Y. M., Owh, C., Chee, P. L. and Loh, X. J. (2020) 'Sanitizing agents for virus inactivation and disinfection', View, 1(2), p. e16. doi: 10.1002/viw2.16.

McDonnell, G. and Russell, A. D. (1999) 'Antiseptics and disinfectants: Activity, action, and resistance, Clinical Microbiology Reviews, 12(1), pp. 147-179. doi: 10.1128/CMR.12. 1.147 .

Mustapha, A., Cadnum, J. L., Alhmidi, H. and Donskey, C. J. (2018) 'Evaluation of novel chemical additive that colorizes chlorine-based disinfectants to improve visualization of surface coverage', American Journal of Infection Control, 46(1), pp. 119-121. doi: 10.1016/j.ajic.2017.09.019.

Nechyporenko, O. L., Berezovskyy, A. V., $\quad$ Fotina, H. A., Petrov, R. V. and Fotina, T. I. (2019) 'Determination of acute toxicity parameters of "Zoodizin" disinfectant', Ukrainian Journal of Veterinary and Agricultural Sciences, 2(2), pp. 41-44. doi: 10.32718/ujvas2-2.09.

Orobchenko, O. L., Roman'ko, M. Ye., Paliy, A. P., Dotsenko, R. V., Morozenko, D. V., Gliebova, K. V., Doletskyi, S. P., and Palii, A. P. (2020) 'Evaluation of $\mathrm{Ag}, \mathrm{Cu}, \mathrm{Fe}$ and $\mathrm{MnO}_{2}$ nanoparticle mixture effect on histomorphological state of internal organs and tissues in laying hens', Ukrainian Journal of Ecology, 10(4). pp. 165-174. doi: 10.15421/2020_184.

Paliy, A. P. and Paliy, A. P. (2019) Technic and Technological Innovations in Dairy Cattle [Tekhniko-tekhnolohichni innovatsii u molochnomu skotarstvi]. Kharkiv: Miskdruk. ISBN 9786176192077. [in Ukrainian].

Paliy, A., Stegniy, B., Muzyka, D., Gerilovych, A. and Korneykov, O. (2016) 'The study of the properties of the novel virucidal disinfectant', Agricultural Science and Practice, 3(3), pp. 41-47. doi: 10.15407/agrisp3.03.041.

Paliy, A. P., Ishchenko, K. V., Marchenko, M. V., Paliy, A. P. and Dubin, R. A. (2018) 'Effectiveness of aldehyde disinfectant against the causative agents of tuberculosis in domestic animals and birds', Ukrainian Journal of Ecology, 8(1), pp. 845-850. doi: 10.15421/2018_283.
Paliy, A. P., Stegniy, B. T., Kuzminov, A. V., Buzun, A. I., Gerilovich, A. P., Bogach, M. V. and Stegniy, M. Yu. (2020a) "Effectiveness of aldehyde disinfectant "DZPT-2" against the African swine fever virus', Ukrainian Journal of Ecology, 10(3), pp. 131-138. doi: 10.15421/2020_146.

Paliy, A. P., Sumakova, N. V., Rodionova, K. O., Nalivayko, L. I., Boyko, V. S., Ihnatieva, T. M., Zhigalova, O. Ye., Dudus, T. V., Anforova, M. V. and Kazakov, M. V. (2020b) 'Disinvasive action of aldehyde and chlorine disinfectants on the test-culture of Toxocara canis eggs', Ukrainian Journal of Ecology, 10(4), pp. 175-183. doi: 10.15421/2020_185.

Paliy, A. P., Zavgorodniy, A. I., Stegniy, B. T. and Palii, A. P. (2020c) Scientific and Methodological Grounds for Controlling the Development and Use of Disinfectants [Naukovo-metodychni osnovy kontroliu rozrobky ta zastosuvannia zasobiv dezinfektsii]. Kharkiv: Miskdruk. ISBN 9786176192374. [in Ukrainian].

Pastushenko, T. B., Marushiy, L. B., Zhukov, A. A. and Pilipenko, Yu. A. (1985) 'Express method for determining semilethal doses of chemicals' [Ekspress-metod dlya opredeleniya srednesmertel'nykh doz khimicheskikh veshchestv], Hygiene and Sanitation [Gigiena i sanitariya], 6, pp. 46-47. [in Russian].

Prozorovskiy, V. B. (1962) 'Using the least squares method for probit analysis of mortality curves' [Ispol'zovanie metoda naimen'shikh kvadratov dlya probit-analiza krivykh letal'nosti]. Pharmacology and Toxicology [Farmakologiya i toksikologiya], 25(1), pp. 115-119. [in Russian].

Ribeiro, M. M., Neumann, V. A., Padoveze, M. C. and Graziano, K. U. (2015) 'Efficacy and effectiveness of alcohol in the disinfection of semi-critical materials: a systematic review', Revista Latino-Americana de Enfermagem, 23(4), pp. 741-752. doi: 10.1590/0104-1169.0266.2611.

Rutala, W. A. and Weber, D. J. (2016) 'Disinfection, sterilization, and antisepsis: An overview', American Journal of Infection Control, 44(5 suppl.), pp. e1-e6. doi: 10.1016/j.ajic. 2015.10.038

Saccucci, M., Bruni, E., Uccelletti, D., Bregnocchi, A., Sarto, M. S., Bossù, M., Di Carlo, G. and Polimeni, A. (2018) 'Surface disinfections: Present and future', Journal of Nanomaterials, 2018, p. 8950143. doi: 10.1155/2018/8950143.

Shkromada, O., Skliar, O., Paliy, Andr., Ulko, L., Gerun, I., Naumenko, O., Ishchenko, K., Kysterna, O., Musiienko, O. and Paliy, Anat. (2019) 'Development of measures to improve milk quality and safety during production', Eastern-European Journal of Enterprise Technologies, 3(11), pp. 30-39. doi: 10.15587/17294061.2019.168762.

Stegniy, B. T., Paliy, A. P., Pavlichenko, O. V., Muzyka, D. V., Tkachenko, S. V. and Usova, L. P. (2019) 'Virucidal properties of innovative disinfectant to Avian influenza virus and Newcastle disease virus', Journal for Veterinary Medicine, Biotechnology and Biosafety, 5(3), pp. 27-33. doi: 10.36016/JVMBBS-2019-5-3-6.

Takagi, G. and Yagishita, K. (2020) 'Principles of disinfectant use and safety operation in medical facilities during Coronavirus disease 2019 (COVID-19) outbreak', SN Comprehensive Clinical Medicine, 2(8), pp. 1041-1044. doi: 10.1007/s42399-020-00413-x.

Zavgorodniy, A. I., Stegniy, B. T., Paliy, A. P., Gorzheiev, V. M. and Smirnov, A. M. (2013) Scientific and Practical Aspects of Disinfection in Veterinary Medicine [Naukovi ta praktychni aspekty dezinfektsii u veterynarii]. Kharkiv: FOP Brovin O. V. ISBN 9789662445596. [in Ukrainian]. 